\title{
Comparison of Thermal Decomposition of Polystyrene Products vs. Bio-Based Polymer Aerogels
}

\author{
SUZANNE SELEEM'1 Department of Natural Sciences, Central State University, Wilberforce, OH, USA; MITCHELL HOPKINS, \\ JORDAN OLIVIO, and DAVID A. SCHIRALDI, Department of Macromolecular Science and Engineering, Case Western Reserve \\ University, Cleveland, OH, USA.
}

\begin{abstract}
Samples of polystyrene (PS), extended polystyrene foam (EPS foam), and 3 bio-based foam-like polymer/ clay aerogels were produced, and examined under pyrolysis conditions. The polystyrene products produced pyrolysis products including toluene, styrene, benzaldehyde, and 4-phenyl-1-butyne; all consistent with previous reports. These highly flammable volatiles would be further expected to combust under flame conditions, producing carbon monoxide and carbon dioxide; prior work suggests that carbon monoxide poses the greatest health risk from the burning of both polystyrene and EPS. Pectin and alginate carbohydrate polymer aerogels, subjected to the same pyrolysis conditions as the polystyrene materials, produced products which were generally consistent with prior literature, and presented only moderate known health risks (similar to those of the EPS pyrolysis). As with PS and EPS foams, the alginate and pectin aerogel by-products are flammable, and are expected to be converted to carbon oxides. Casein, a milk-derived protein, generated organic nitriles and aromatic compounds under pyrolysis conditions, again consistent with literature for proteins in general. While none of the bio-based pyrolysis products of this study pose known significant health risks, it is possible that some of nitriles could be converted to hydrogen cyanide, leading to the recommendation that such protein-based products be further investigated prior to implementation in consumer/civil engineering applications.
\end{abstract}

\section{INTRODUCTION}

Polymer foams find applications in a wide range of products, including food and consumer product packaging, transportation, and construction (RuizHerrero and Rodríguez-Perez 2015). The vast majority of these foams, most typically produced by expansion of polyethylene, polystyrene, or polyurethane, are petrochemically-derived, and consequently some of them are highly flammable. An example of such a foam product is extended polystyrene (EPS) produced from benzene and ethylene, then foamed to reduce its density from $1.04 \mathrm{~g} / \mathrm{cm}^{3}$ to approximately 0.02 to $0.05 \mathrm{~g} / \mathrm{cm}^{3}$ (Zarr and Pintar 2012). Because this foam is primarily air on a volume basis, its thermal conductivity similarly mirrors that of air (a typical value for EPS might be $0.033 \mathrm{~W} /(\mathrm{mK})$ vs. that for air of $0.025 \mathrm{~W} /(\mathrm{mK})$ ) (Zarr and Pintar 2012).

Polymer aerogels have been proposed as replacements for polymer foams in a range of applications (Somlai et al. 2006; Pojanavaraphan et al. 2010; Wang and Schiraldi 2013; Chen et al. 2012; Shang et al. 2016;

\footnotetext{
${ }^{1}$ Address correspondence to Suzanne Seleem, Department of Natural Sciences, Central State University, Wilberforce, $\mathrm{OH}$ 45384. Email: sxs1536@case.edu
}

Chen et al. 2013). These materials, most commonly produced by freeze drying of aqueous dispersions of smectite clays and polymers, or by supercritical drying of polymer gels in organic solvents, possess densities in the 0.05 to $0.15 \mathrm{~g} / \mathrm{cm}^{3}$ range, have EPS-like thermal conductivities, and can be produced from a wide range of polymers (Schiraldi 2015). Especially interesting are polymer aerogels produced from bio-based polymers, converted to aerogels via the freeze-drying process; allowing the combination of a renewable material with a very low environmental impact process (the only effluent from the freeze-drying route to aerogels is typically just water vapor). Surprisingly, and unlike EPS and most other commercial foam materials, many of the bio-based polymer aerogels exhibit extremely low flammabilities (Chen et al. 2012; Shang et al. 2016). Not established to date is whether typical bio-based polymer aerogels release toxic gases upon combustion; both low flammability and low-smoke toxicity are necessary for many foam-replacement applications. Wool is a good example of a bio-base polymer which releases a highly toxic combustion product, in this case HCN gas (Beyler and Hirschler 2002). In order for the bio-based polymer aerogels 
to truly represent environmental improvements over EPS foam, the question of their combustion products needs to be answered. The present work examines the combustion products of a series of bio-based polymer aerogels, comparing these results with the products of EPS combustion.

\section{MATERIALS AND METHODS}

\section{Materials}

Casein, pectin, ammonium alginate, and sodium hydroxide (all Fisher Scientific), sodium montmorillonite $\left(\mathrm{Na}^{+}-\mathrm{MMT}\right.$; PGW grade, cation exchange capacity of 145 meq/100 g; Nanocor Inc.), extended EPS foam (FOAMULAR ${ }^{\circledR}$ 150, Owens Corning), and Cellofoam ${ }^{\circledR}$ (Cellofoam North America Inc.) were all used as received. Deionized (DI) water was obtained using a Barnstead|Thermolyne ROpure ${ }^{\circledR}$ reverse osmosis system. Finished polymer resins, foams, and aerogels tested in this study are given in Table 1; densities are $\pm 5 \%$ of the values given. The commercial product compositions are as given by the manufacturers' data sheets.

\section{Aerogel Preparation}

Polymer/clay aerogels were produced from casein (milk protein) (Wang and Schiraldi 2013), alginate (derived from seaweed) (Chen et al. 2012), and pectin (a gelling fruit-based carbohydrate) (Chen et al. 2013); detailed preparations can be found in the cited references. In each case, separate mixtures of polymer and inorganic fillers-clay were produced by high shear blending, then the polymer and fillers mixtures were combined under low shear blending. The aqueous mixtures were transferred to $2 \mathrm{~cm}$ diameter cylindrical polystyrene vials and immediately frozen in a solid carbon dioxide/ethanol bath $\left(\sim-80{ }^{\circ} \mathrm{C}\right)$ before being placed in a VirTis Advantage EL-85 lyophilizer for 4 days, where high vacuum was applied to sublime the ice.

\section{Analytical Methods}

Thermogravimetric analyses (TGA) were carried out using a TA Instruments Q500, operating under nitrogen and under air environments, with a $10{ }^{\circ} \mathrm{C}$ temperature ramp rate. Pyrolysis GC-MS was carried out in air at the University of Dayton Research Institute, using a CDS Analytical Model 2000 Pyroprobe equipped with a Carbolite TZF 12/38/400 furnace, connected to an HP5890/5970 GC-MS (Agilent), and total ion methodology (sample heated at $100 \%$ $\min$ to $\left.1000^{\circ} \mathrm{C}\right)$.

\section{RESULTS AND DISCUSSION}

Two different extended polystyrene polymers used as commercial insulating materials, and three polymer/ clay aerogels produced using casein, alginate, and pectin as the biopolymer matrixes, were characterized and subjected to TGA and pyrolysis GC/MS analysis. This testing provided a better understand of each materials' decomposition under air and under nitrogen, and determined the decomposition gases which were produced by these materials at elevated temperature. Descriptions of the materials tested are given in Table 1 .

Test materials were subjected to thermal degradation conditions under both air and nitrogen

Table 1

Materials evaluated

\begin{tabular}{|c|c|c|}
\hline Materials & Composition & Density $\left(\mathrm{g} / \mathrm{cm}^{3}\right)$ \\
\hline $\begin{array}{l}\text { Polystyrene pellets } \\
\text { (Aldrich) }\end{array}$ & Polystyrene & 1.05 \\
\hline $\begin{array}{l}\text { Extended polystyrene } \\
\text { insulation pink } \\
\left(\text { FOAMULAR }^{\circledR} 150\right)\end{array}$ & $\begin{array}{l}\text { Polystyrene } 80-90 \% \text { wt., } \\
\text { 1-chloro-1-1-diffluoroethane } 7-12 \% \text { wt., } \\
\text { hexabromocyclododecane } 0.5-1.5 \% \text { wt., talc } 0-2 \% \text { wt. }\end{array}$ & 0.021 \\
\hline $\begin{array}{l}\text { Extended polystyrene } \\
\text { insulation white } \\
\left(\text { Cellofoam }^{\circledR}\right)\end{array}$ & $\begin{array}{l}\text { Polystyrene foam } 95-100 \% \text { wt., } \\
\text { pentanes (n-pentane, isopentane \& cyclopentane) } \leq 2 \% \text { wt. }\end{array}$ & 0.015 \\
\hline Pectin & $50 \%$ pectin, $50 \% \mathrm{Na}^{+}-\mathrm{MMT}$. & 0.10 \\
\hline Casein & $50 \%$ casein, $50 \% \mathrm{Na}^{+}-\mathrm{MMT}$. & 0.11 \\
\hline Alginate & $72 \%$ alginate, $28 \% \mathrm{Na}^{+}-\mathrm{MMT}$. & 0.075 \\
\hline
\end{tabular}


Table 2

TGA of the subject materials

\begin{tabular}{|c|c|c|c|c|c|}
\hline $\begin{array}{l}\text { Polymer } \\
\text { [trademark name] } \\
\text { (\% filler) }\end{array}$ & Environment & $\begin{array}{l}\text { Onset } \\
\text { degradation } \\
\text { temperature }{ }^{\circ} \mathrm{C}\end{array}$ & $\begin{array}{l}\text { Degradation } \\
\text { range }{ }^{\circ} \mathrm{C}\end{array}$ & $\begin{array}{l}\text { Weight } \\
\text { loss \% }\end{array}$ & $\begin{array}{l}\text { Residual } \\
\text { weight \% }\end{array}$ \\
\hline \multirow{2}{*}{$\begin{array}{l}\text { EPS white } \\
\quad\left[\text { Cellofoam }{ }^{\circledR}\right]\end{array}$} & Air & 325 & $325-425$ & 100 & 0 \\
\hline & Nitrogen & 375 & $375-450$ & 100 & 0 \\
\hline \multirow{2}{*}{$\begin{array}{l}\text { EPS pink } \\
\left.\qquad \text { FOAMULAR }^{\circledR} 150\right]\end{array}$} & Air & 325 & $325-425$ & 100 & 0 \\
\hline & Nitrogen & 375 & $375-450$ & 100 & 0 \\
\hline \multirow[t]{2}{*}{ Polystyrene } & Air & 325 & $325-425$ & 100 & 0 \\
\hline & Nitrogen & 375 & $375-450$ & 100 & 0 \\
\hline \multirow{7}{*}{$\begin{array}{l}\text { Casein aerogel } \\
(50)\end{array}$} & Air & 50 & $50-100$ & 10 & \\
\hline & & & $100-200$ & 5 & \\
\hline & & & $200-250$ & 15 & 50 \\
\hline & & & $250-800$ & 20 & \\
\hline & Nitrogen & 50 & $50-100$ & 10 & \\
\hline & & & $200-400$ & 40 & 45 \\
\hline & & & $>400$ & 5 & \\
\hline \multirow{3}{*}{$\begin{array}{l}\text { Alginate aerogel } \\
\text { (28) }\end{array}$} & Air & 450 & $450-500$ & 85 & 5 \\
\hline & & & $500-550$ & 10 & 3 \\
\hline & Nitrogen & 375 & $375-475$ & 95 & 5 \\
\hline \multirow{5}{*}{$\begin{array}{l}\text { Pectin aerogel } \\
(50)\end{array}$} & Air & 40 & $40-200$ & 12 & \\
\hline & & & $200-450$ & 33 & 47 \\
\hline & & & $450-585$ & 8 & \\
\hline & Nitrogen & 40 & $40-250$ & 10 & \\
\hline & & & $250-800$ & 38 & 52 \\
\hline
\end{tabular}

atmospheres, with rate losses characterized by TGA (Table 2). Both commercial polystyrene samples showed degradation onset temperatures of $325^{\circ}$ and $375{ }^{\circ} \mathrm{C}$, under air and nitrogen atmospheres, respectively, consistent with prior literature reports; all of the polystyrene samples fully degraded, with no residual material left by $500^{\circ} \mathrm{C}$ (Figs. 1 to 4 ). The casein, pectin, and alginate aerogels exhibited more complex decomposition behaviors than seen for polystyrene, with multiple weight loss steps observed, but ultimately with nearly all of the organic matter consumed by 500 ${ }^{\circ} \mathrm{C}$ under air, and $800^{\circ} \mathrm{C}$ under nitrogen atmosphere. The observed behaviors of alginate (Figs. 5, 6) and casein (Figs. 7, 8) mirror previously-reported TGA results (Kong et al. 2009, Moldoveanu et al. 2013). Residual weights of the aerogels-with the exception of alginate-closely mirrored the weight percentage of the montmorillonite clay filler in the samples. Montmorillonite clay is known to be thermally stable, and is converted into a ceramic material under natural gas fire conditions present in cone calorimetry testing (Chen et al. 2012). For pectin, degradation started at $40^{\circ} \mathrm{C}$ under both air and nitrogen atmospheres (Figs. $9,10)$. The sample resisted complete degradation under nitrogen atmosphere until $800{ }^{\circ} \mathrm{C}$, losing $48 \%$ of the original weight.

Decomposition products identified using total ion chromatography, with $100 \%$ gasification, are given in Table 3. The polystyrene pellets and both commercial EPS foams gave similar decomposition products: styrene, toluene, benzaldehyde, 4-phenyl1-butyne, and 2-nitropropylbenzene; all but the latter being readily rationalized from the starting polymer structure (Figs. 11, 12). Previous workers have 


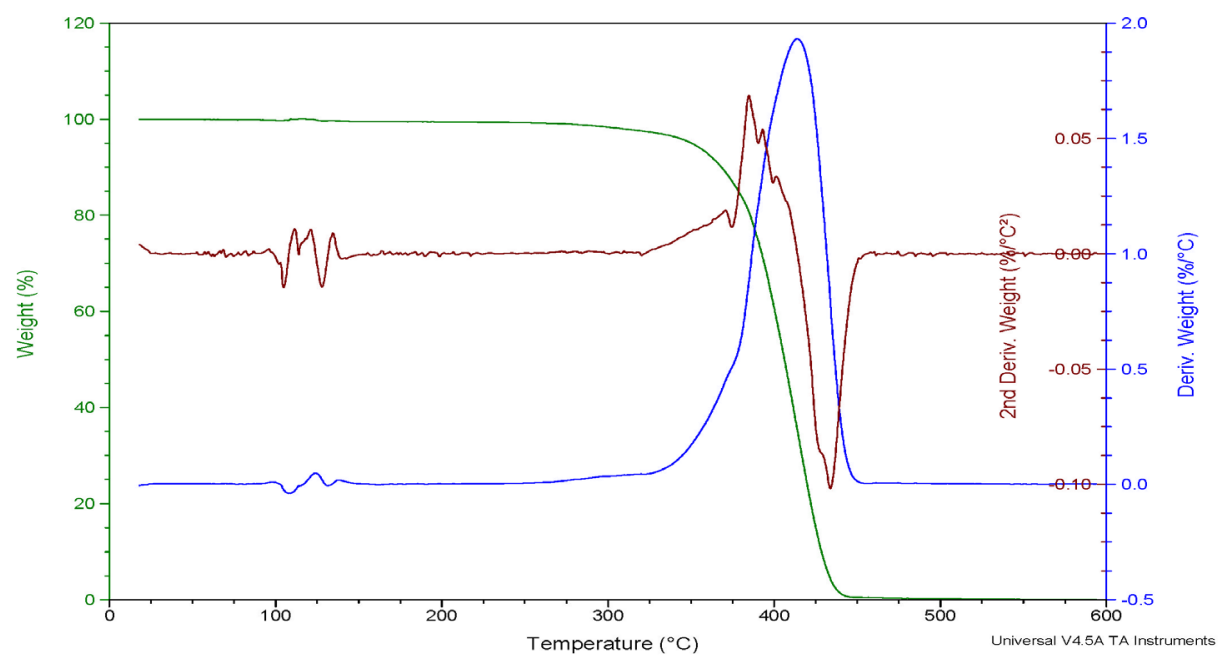

FIGURE 1. Thermogravimetric degradation analysis of extended polystyrene insulation (pink) in air

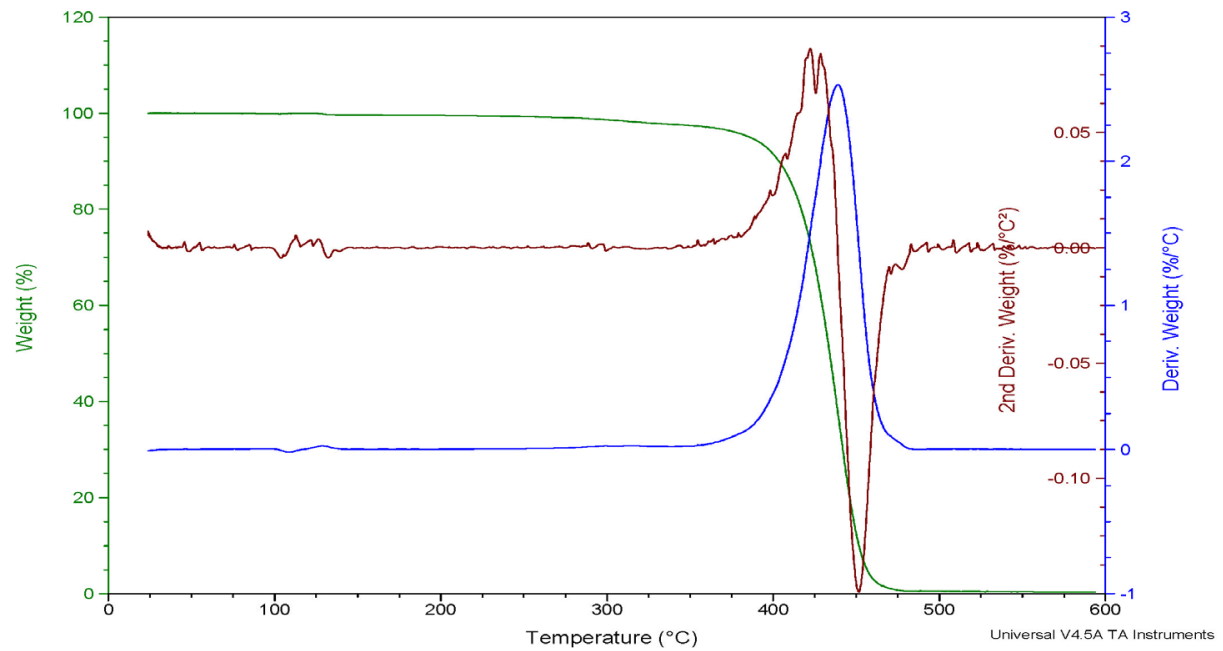

FIGURE 2. Thermogravimetric degradation analysis of extended polystyrene insulation (pink) in nitrogen

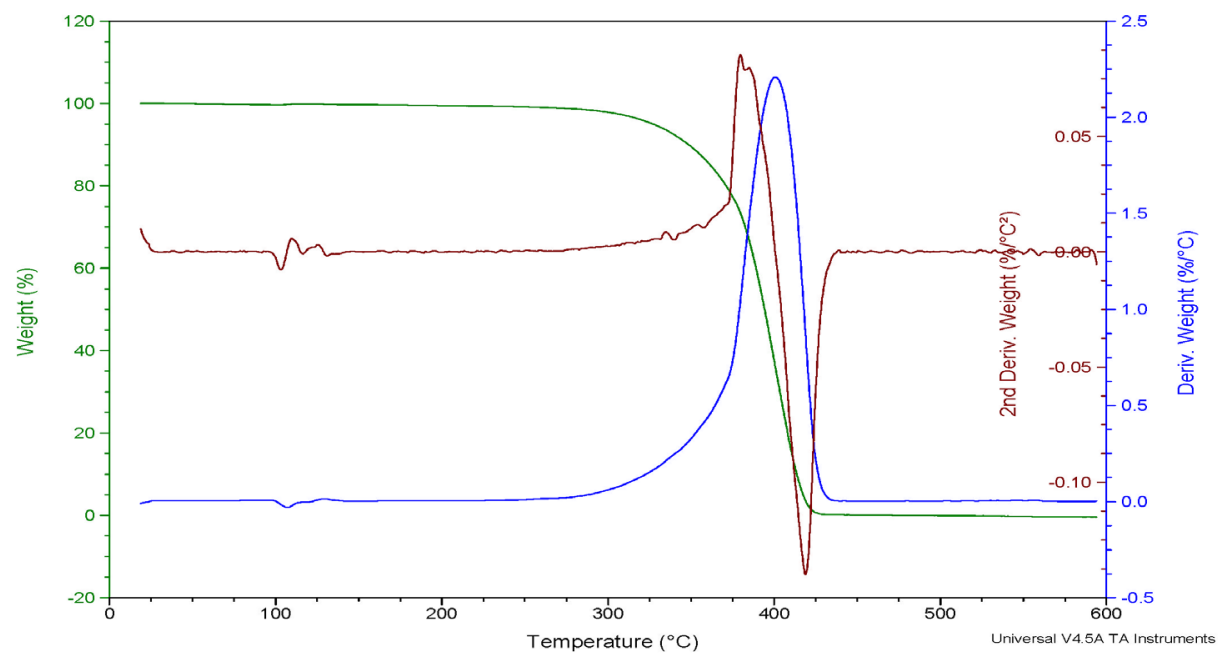

FIGURE 3. Thermogravimetric degradation analysis of extended polystyrene insulation (white) in air 


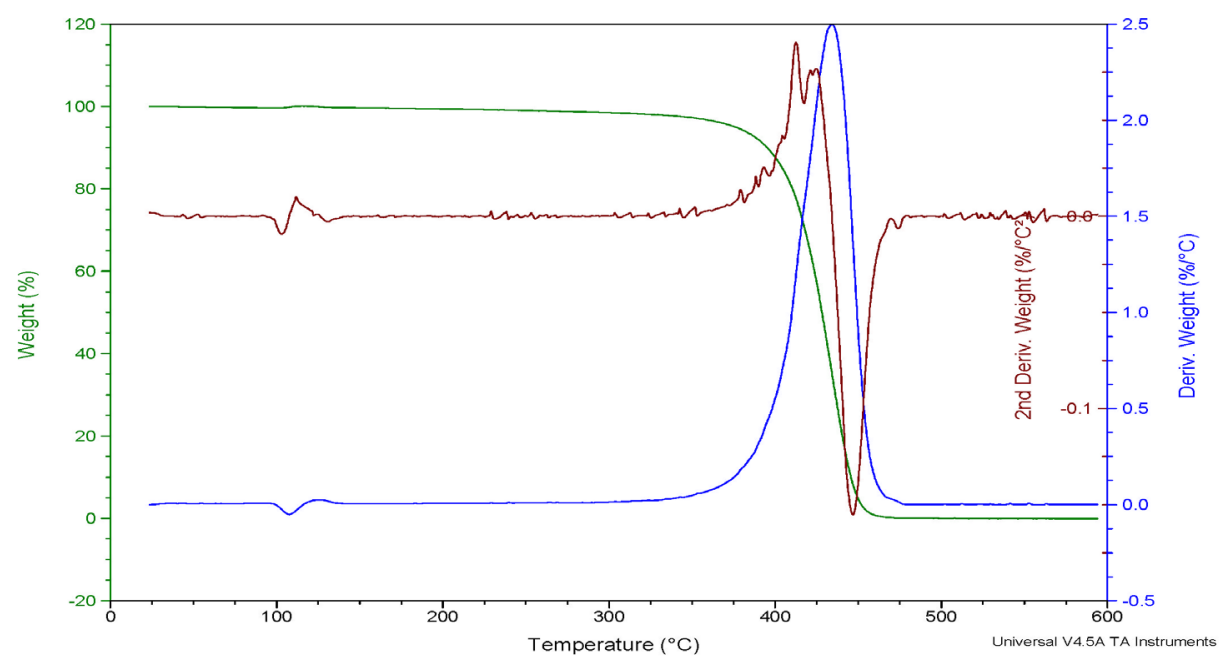

FIGURE 4. Thermogravimetric degradation analysis of extended polystyrene insulation (white) in nitrogen

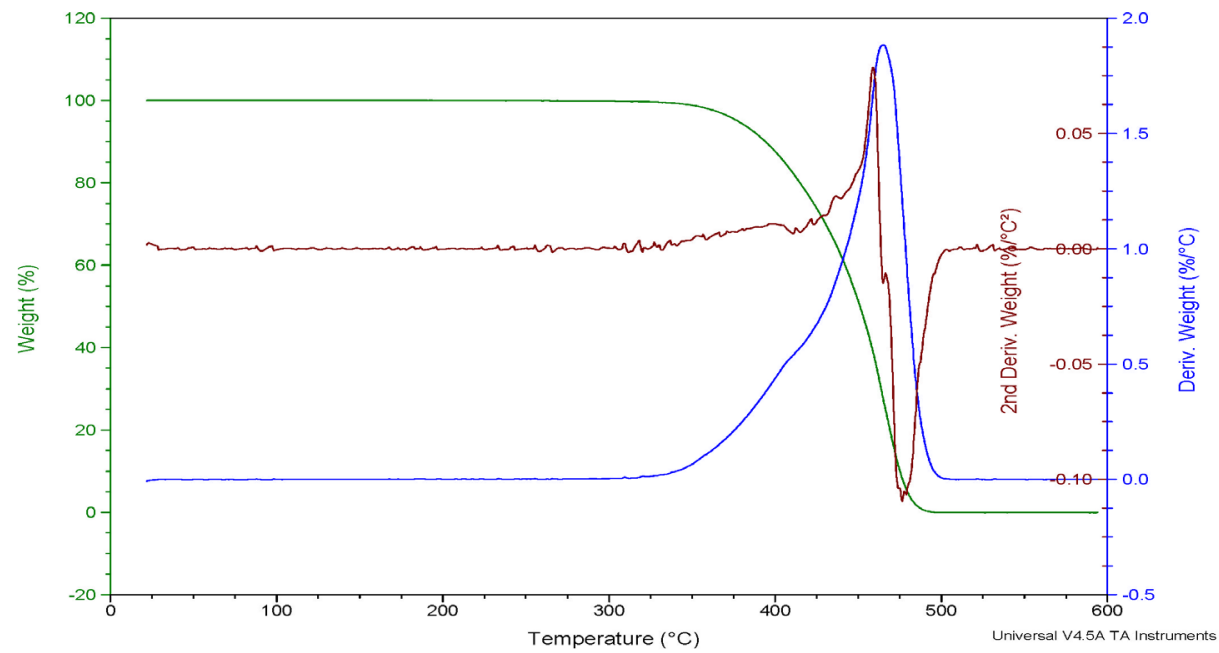

FIGURE 5. Thermogravimetric degradation analysis of alginate in nitrogen

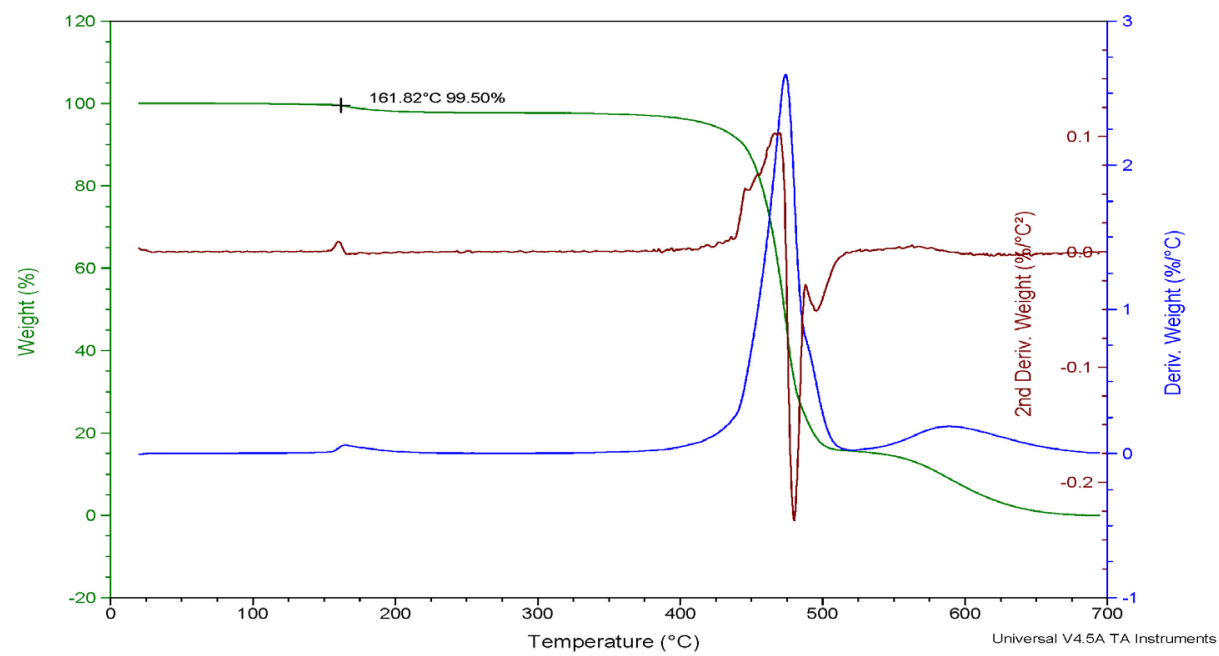

FIGURE 6. Thermogravimetric degradation analysis of alginate in air 


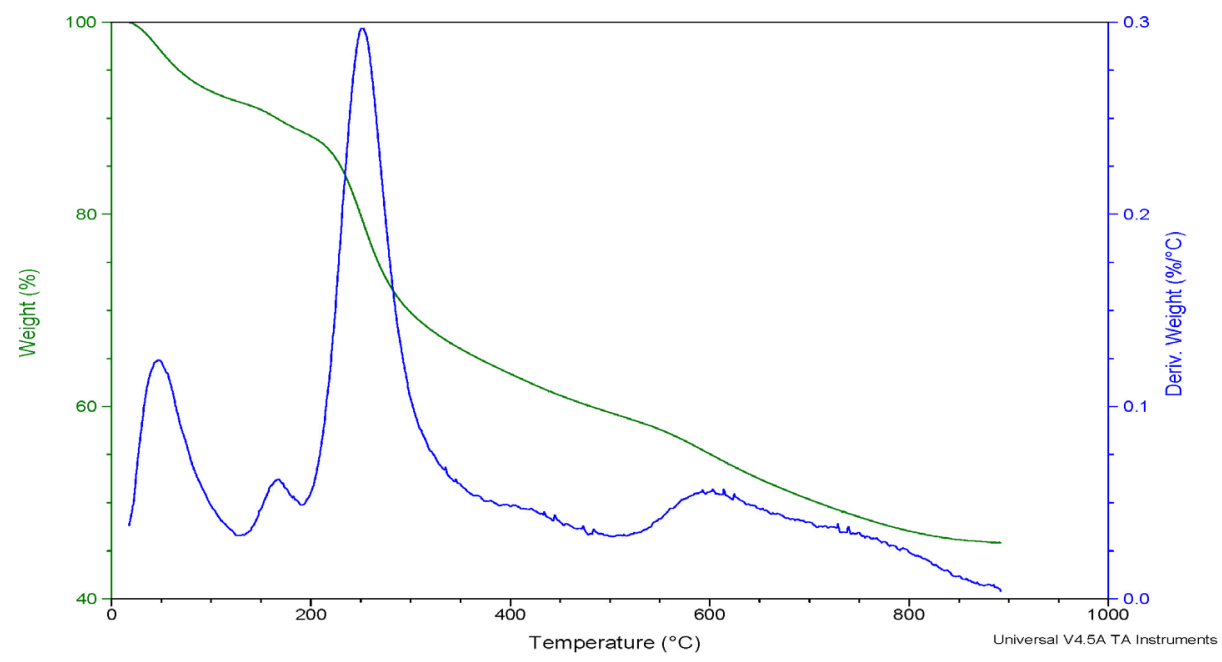

FIGURE 7. Thermogravimetric degradation analysis of casein in air

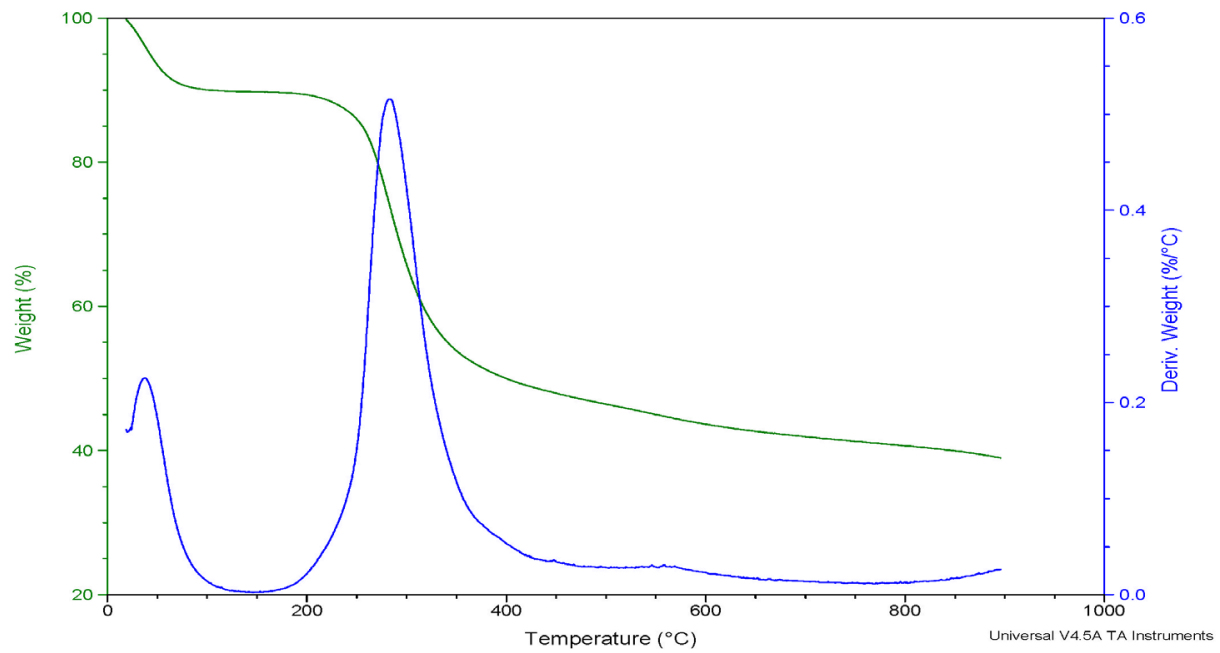

FIGURE 8. Thermogravimetric degradation analysis of casein in nitrogen

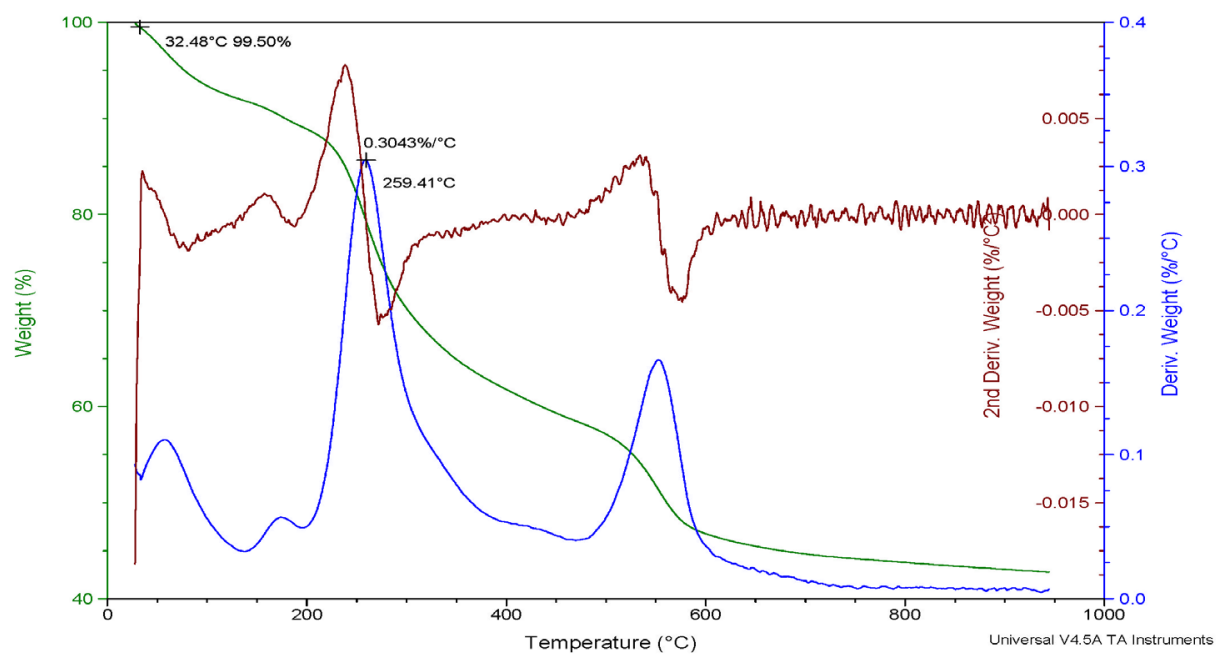

FIGURE 9. Thermogravimetric degradation analysis of pectin in air 


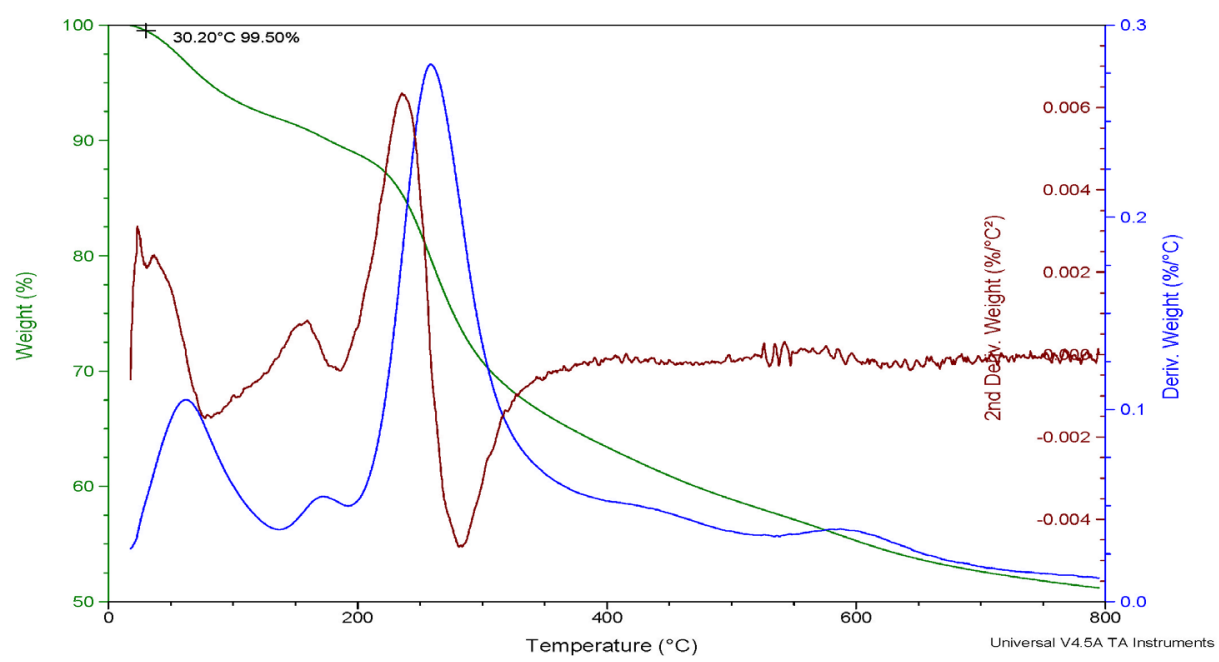

FIGURE 10. Thermogravimetric degradation analysis of pectin in nitrogen

Table 3

Gasified decomposition products

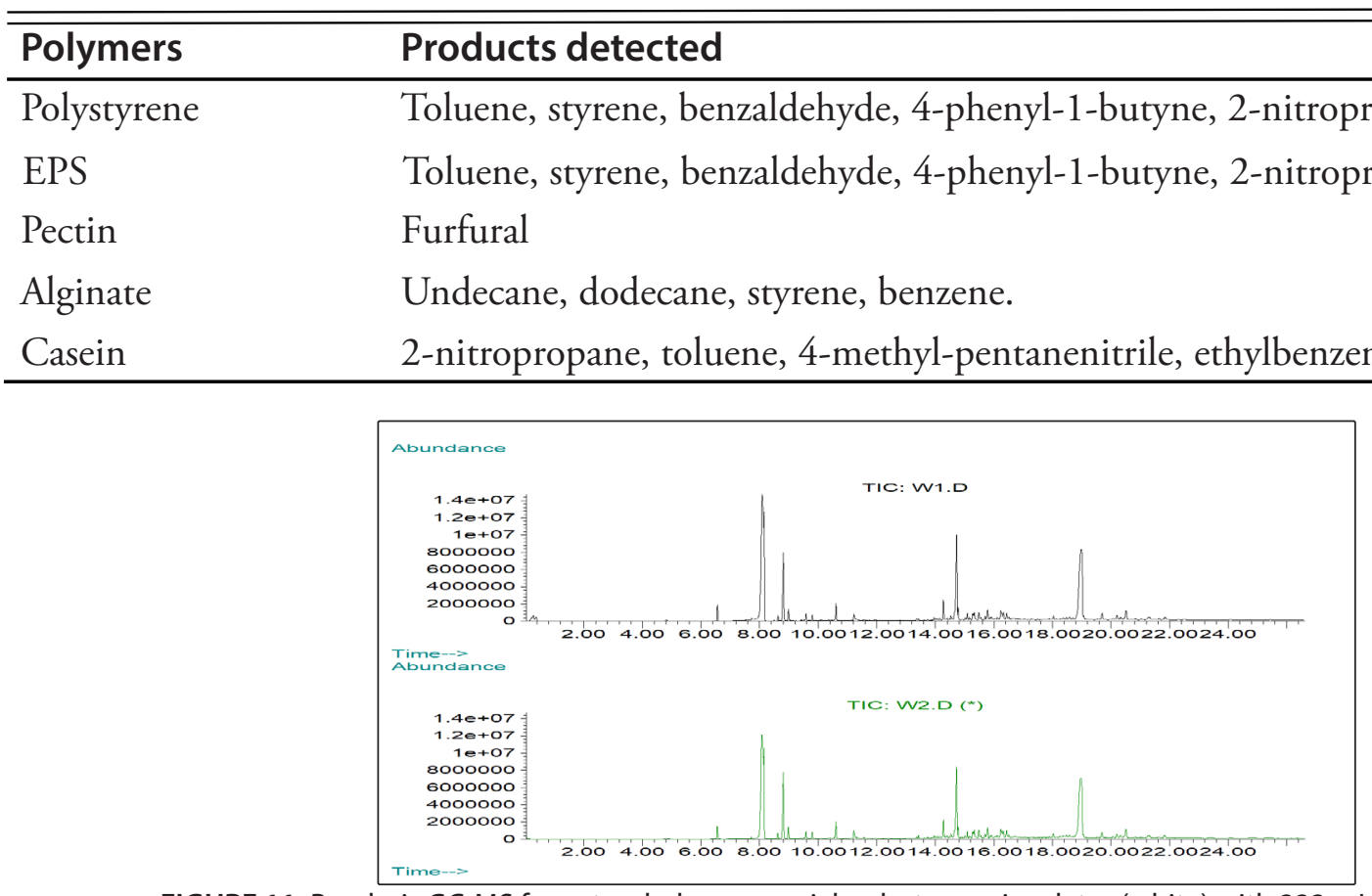

FIGURE 11. Pyrolysis GC-MS for extended commercial polystyrene insulator (white) with $222 \mathrm{~mL} / \mathrm{min}$. flow rate. Top: run 1, bottom: run 2 .

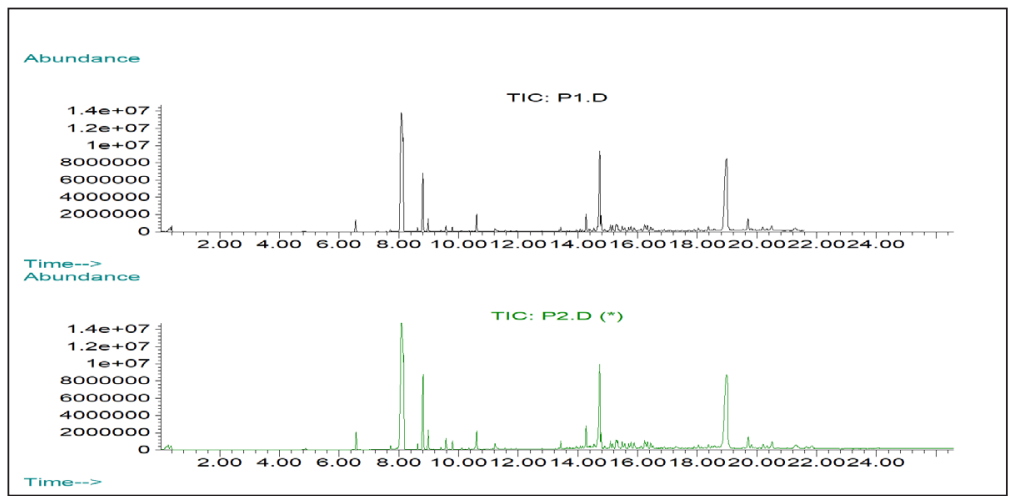

FIGURE 12. Pyrolysis GC-MS for commercial polystyrene insulator (pink) with $222 \mathrm{~mL} / \mathrm{min}$. flow rate. Top: run 1, bottom: run 2 . 
reported that, depending on conditions, the major decomposition products of polystyrene are styrene and benzaldehyde (Beyler and Hirschler 2002), and possibly also phenyl ethanol, styrene oxide, cumene, and acetophenone (Pfäffli et al. 1978). A full review of decomposition products is given in Gurman et al. (1987), which showed the styrene concentrations plus the decomposition gases is significantly impacted by pyrolysis temperature. A review of prior polystyrene degradation/combustion literature data reiterated the range of thermal decomposition products possible, but makes the important point that these by-products are themselves highly flammable. Hence, the major toxicity issue associated with flaming decomposition of this polymer is likely due to carbon monoxide, which is produced in high levels, along with carbon dioxide (Gurman et al. 1987). Under non-flaming conditions, when the range of organic by-products are observed, the toxicity of polystyrene by-products are much lower.

Pectin, depending on conditions, has been previously shown to generate aldehydes, such as formaldehyde, acetaldehyde, acetone, acrolein, propionaldehyde, crotonaldehyde, methyl ethyl ketone, and butyraldehyde (Zhou et al. 2011). In our study, a different aldehyde, furfural, was the volatile component that was detected (Fig. 13). While pectin, a carbohydrate, does not contain the furan moiety present in furfural, it is not difficult to imagine a series of dehydration and decarboxylation reactions which could lead to this product. Furfural is widely known to be a pyrolysis product of lignocellulosic feedstocks, such as rice and oat husks (Gallo et al. 2013).

Alginate, also a carbohydrate, showed consistently small amounts of undecane and dodecane released upon degradation (Fig. 14). In a repeat pyrolysis, styrene and benzene were also observed. While these hydrocarbons were repeatable, it is not obvious how they could be produced from alginate, leading us to suspect that this is an artifact of the column/test method used. No other volatile products were observed from alginate degradation. Flammability studies of alginate aerogels have shown them to be among the least flammable foam-like materials known, a fact inconsistent with hydrocarbon by-products, and more consistent with a near absence of flammable gases (Chen et al. 2012; Shang et al. 2016).

Casein pyrolysis was found to produce 2-nitropropane, toluene, 4-methyl-pentanenitrile, ethylbenzene, and benzonitrile (Fig. 15), which are different from the carbon monoxide, carbon dioxide, water, ammonia, and isocyanic acid products previously reported using FTIR of thermally-degraded polymer (Moldoveanu et al. 2013). Toluene and a number of nitriles, including those detected in this study, have been

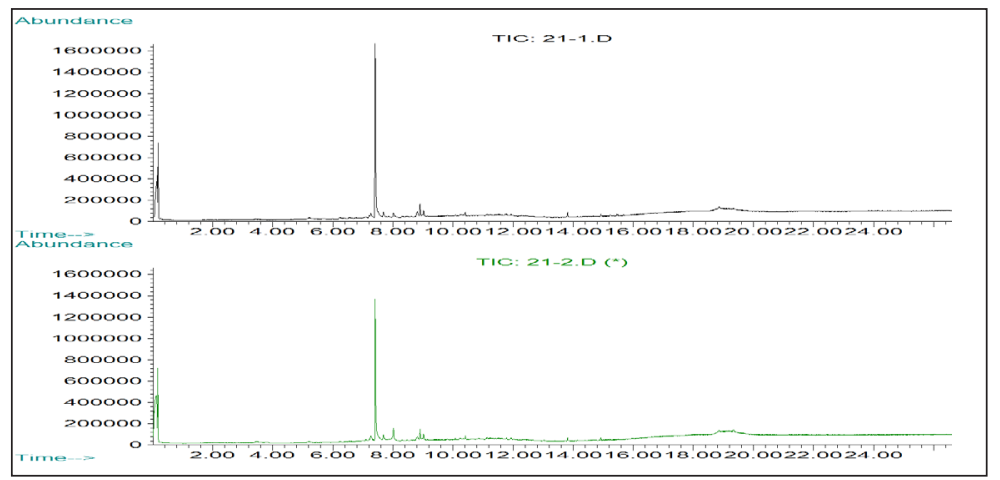

FIGURE 13. Pyrolysis GC-MS for pectin aerogel with $222 \mathrm{~mL} / \mathrm{min}$. flow rate. Top: run 1, bottom: run 2.

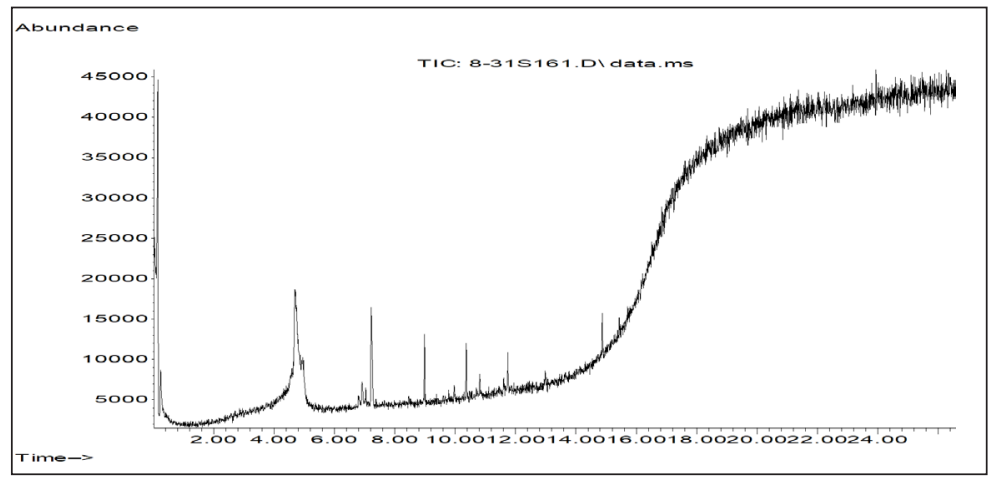

FIGURE 14. Pyrolysis GC-MS for alginate aerogel with $222 \mathrm{~mL} / \mathrm{min}$. flow rate 


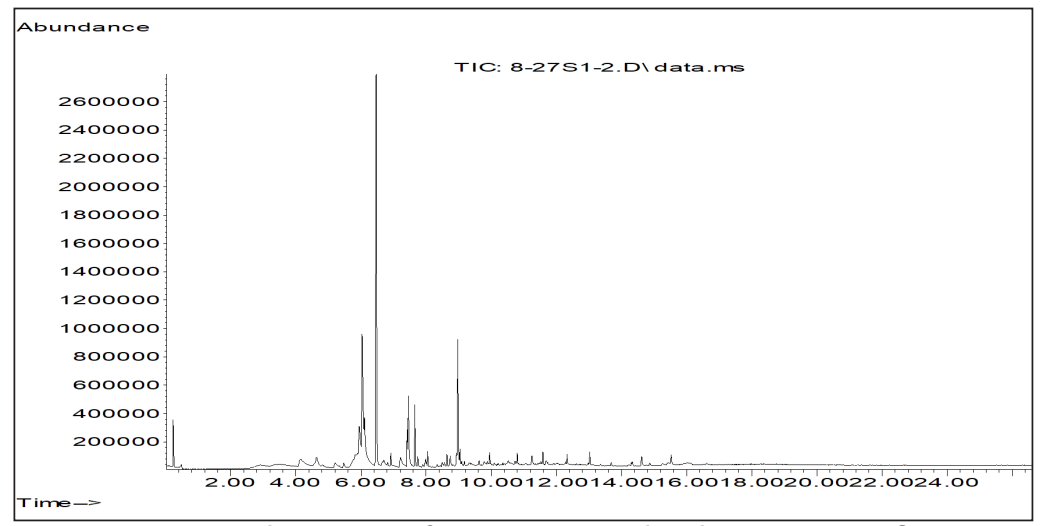

FIGURE 15. Pyrolysis GC-MS for casein aerogel with $222 \mathrm{~mL} / \mathrm{min}$. flow rate

Table 4

Published toxicities of decomposition products

\begin{tabular}{|c|c|c|c|c|}
\hline $\begin{array}{l}\text { Chemical } \\
\text { byproduct }\end{array}$ & $\begin{array}{l}\text { Original } \\
\text { polymer }\end{array}$ & CAS-No & Carcinogen & $\begin{array}{l}\text { Health } \\
\text { hazards* }\end{array}$ \\
\hline Undecane & Aliginate & $1120-21-4$ & $\begin{array}{l}\leq 0.1 \\
\text { Probable/possible/confirmed in humans }\end{array}$ & $1^{a}$ \\
\hline Furfural & Pectin & $98-01-1$ & $\begin{array}{l}\leq 0.1 \\
\text { Probable/possible/confirmed in humans }\end{array}$ & $2^{\mathrm{b}}$ \\
\hline Benzaldehyde & EPS & $100-52-7$ & No data available & $2^{c}$ \\
\hline Nitropropane & Casein & $79-46-9$ & Classified. Proven for animals. & $2^{\mathrm{d}}$ \\
\hline $\begin{array}{l}\text { Nitropropyl } \\
\text { benzene }\end{array}$ & EPS & $7137-54-4$ & $\begin{array}{l}\leq 0.1 \\
\text { Probable/possible/confirmed in humans }\end{array}$ & $4^{\mathrm{e}}$ \\
\hline Phenyl butyne & EPS & $16520-62-0$ & No data available & $2^{\mathrm{f}}$ \\
\hline Benzene & Aliginate & $71-43-2$ & Classified. Confirmed for humans. & $2^{g}$ \\
\hline Benzonitrile & Casein & $100-47-0$ & No data available & $2^{\mathrm{h}}$ \\
\hline Dodecane & Aliginate & $112-40-3$ & No data available & $2^{\mathrm{i}}$ \\
\hline Ethyl benzene & Casein & $100-41-4$ & Possible for humans & $2^{j}$ \\
\hline Styrene & EPS, aliginate & $100-42-5$ & Possible/proven for humans & $2^{\mathrm{k}}$ \\
\hline Toluene & EPS, casein & $108-88-3$ & Not classifiable for humans & $2^{1}$ \\
\hline $\begin{array}{l}\text { Methyl } \\
\text { pentanenitrile }\end{array}$ & Casein & $542-54-1$ & $\begin{array}{l}\leq 0.1 \\
\text { Probable/possible/confirmed in humans }\end{array}$ & $2^{\mathrm{m}}$ \\
\hline \multicolumn{5}{|c|}{${ }^{*} 0=$ minimal hazard; $1=$ slight hazard; $2=$ moderate hazard; $3=$ serious hazard $4=$ severe hazard } \\
\hline \multicolumn{5}{|c|}{$\begin{array}{l}\text { a MSDS CAS-No 1120-21-4, Sigma-Aldrich Inc. } \\
{ }^{\mathrm{b}} \text { MSDS CAS-No 98-01-1, Sigma-Aldrich Inc. } \\
{ }^{\mathrm{c}} \text { MSDS CAS-No 100-52-7, ScienceLab.com Inc. } \\
{ }^{\mathrm{d}} \text { MSDS CAS-No 79-46-9, ScienceLab.com Inc. } \\
{ }^{\mathrm{e}} \text { MSDS CAS-No 7137-54-4, Sigma-Aldrich Inc. } \\
{ }^{\mathrm{f}} \text { MSDS CAS-No 16520-62-0, Sigma-Aldrich Inc. } \\
{ }^{\mathrm{g}} \text { MSDS CAS-No 71-43-2, ScienceLab.com Inc. } \\
\end{array}$} \\
\hline
\end{tabular}


demonstrated to be significant products of proteinrich biomass pyrolysis, specifically from $C$. vulgaris algae feedstocks (Wang 2014). In the present work, toluene was the major product, detected in 25 to 40 fold excess compared to individual nitriles and ethyl benzene; these ratios were in the 5 to 10 fold excess in Wang's work, potentially reflecting differences in protein structures and/or the pyrolysis and analytical methodologies.

Published toxicological data on the by-products of polymer pyrolysis detected in the present study are presented in Table 4. Unlike the cited production of HCN from wool, none of the bio-based aerogel pyrolysis products detected herein rise beyond "moderate hazards." As mentioned above, these pyrolysis products themselves are flammable organics in the vapor phase, so while the carbon oxides are expected to be significant combustion products, it is also possible that pyrolysis to organic nitriles could still lead to the ultimate production of $\mathrm{HCN}$. Hodgkin et al., for example, detected both nitriles and HCN in the products produced when wool fabrics are burned (Hodgkin et al. 1983).

Combining the current data, we find that under pyrolysis conditions both polystyrene and extended polystyrene foam degradation products are similar to those previously reported. Carbohydrate-based polymer aerogels produce gaseous by-products which are of relatively low toxicity, which in turn, when burned, could likely be expected to further combust to carbon oxides typical of organic products. Casein, the lone protein tested in aerogel form, produced pyrolysis products typical of previously-reported protein pyrolysis studies. While no highly toxic products were detected from pyrolysis of casein aerogels, it is important to point out that further combustion of nitrile by-products potentially could lead to some level of hydrogen cyanide generation, a point that would need to be further evaluated prior to commercial installation of protein-based aerogels in construction or transportation applications.

In conclusion, polystyrene and EPS foam, under pyrolysis conditions, produce by-products such as toluene, styrene, benzaldehyde, and 4-phenyl-1-butyne which are consistent with previous reports in the literature. These highly flammable volatiles would be further expected to combust under flame conditions, producing primarily carbon monoxide and carbon dioxide; prior work has suggested that carbon monoxide poses the greatest health risk from the burning of
EPS foam. Pectin and alginate carbohydrate polymer aerogels, subjected to the same pyrolysis conditions as the polystyrene materials, produced products which were generally consistent with prior literature, and presented only moderate known health risks (similar to those of the EPS pyrolysis). As with EPS foam, the alginate and pectin aerogel by-products are flammable, and are expected to be converted to carbon oxides. Casein, a milk-derived protein, generated organic nitriles and aromatic compounds, again consistent with known literature for protein pyrolysis in general. While none of the casein pyrolysis products of this study pose known significant health risks, it is possible than some of the nitriles could be converted to hydrogen cyanide in a fire, leading to the recommendation that this point be further investigated prior to implementation of protein-based aerogels in consumer or civil engineering applications.

\section{ACKNOWLEDGEMENTS}

We thank the Department of Macromolecular Science and Engineering at Case Western Reserve University for hosting and facilitating Dr. Seleem while this research was accomplished.

\section{LITERATURE CITED}

Beyler CL, Hirschler MM. 2002. Thermal decomposition of polymers. In: SFPE handbook of fire protection engineering. Vol. 2. Section 1, Chapter 7: 111-131. National Fire Protection Association.

Chen HB, Chiou BS, Wang YZ, Schiraldi DA. 2013. Biodegradable pectin/clay aerogels. ACS Appl Mater Interfaces. 5(5):1715-21. http://dx.doi.org/10.1021/ am3028603

Chen HB, Wang YZ, Sánchez-Soto M, Schiraldi DA. 2012. Low flammability, foam-like materials based on ammonium alginate and sodium montmorillonite clay. Polymer. 53(25):5825-31. https://doi.org/10.1016/j.polymer.2012.10.029

Gallo JMR, Alonso DM, Mellmer MA, Yeap JH, Wong HC, Dumesic JA. 2013. Production of furfural from lignocellulosic biomass using beta zeolite and biomass-derived solvent. Top Catal. 56(18-20):1775-1781. https://doi.org/10.1007/ s11244-013-0113-3

Gurman JL, Baier L, Levin BC. 1987. Polystyrenes: A review of the literature on the products of thermal decomposition and toxicity. Fire Mater. 11(3):109-130. https://doi.org/10.1002/ fam.810110302

Hodgkin JH, Galbraith MN, Chong YK. 1983. Combustion products from burning wool fabric. Fire Mater. 7(4):210-215. https://doi.org/10.1002/fam.810070409

Kong QS, Wang BB, Ji Q, Xia YZ, Guo ZX, Yu J. 2009. Thermal degradation and flame retardancy of calcium alginate fibers. Chinese J Polym Sci. 27(6):807-812. https://doi. org/10.1142/S0256767909004527

Moldoveanu C, Odochian L, Paius CM, Lorela I, Baiceanu A. 2013. Study on the thermal behavior of casein in air. Acta 
Chemica Iasi. 21(1):31-46. https://doi.org/10.2478/achi2013-0004.

Pfäffli P, Zitting A, Vainio H. 1978. Thermal degradation products of homopolymer polystyrene in air. Scand J Work Environ Health. 4(Suppl 2):22-27. https://doi.org/10.5271/ sjweh.2744.

PojanavaraphanT, Magaraphan R, Chiou BS, Schiraldi DA. 2010. Development of biodegradable foamlike materials based on casein and sodium montmorillonite clay. Biomacromolecules. 11(10):2640-46. https://doi.org/10.1021/bm100615a

Ruiz-Herrero JL, Rodríguez-Perez MA. 2015. Polymeric foams. In: Encyclopedia of polymer science and technology. New York: Wiley.p. 1-39. https://doi.org/10.1002/0471440264.pst634

Schiraldi DA. 2015. Polymer aerogels. In: Encyclopedia of polymer science and technology. New York: Wiley. p. 1-18. https://doi.org/10.1002/0471440264.pst637

Shang K, Liao W, Wang J, Wang YT, Wang YZ, Schiraldi DA. 2016. Nonflammable alginate nanocomposite aerogels prepared by a simple freeze-drying and post-cross-linking method. ACS Appl Mater Interfaces. 8(1):643-650. http:// doi.org/10.1021/acsami.5b09768

Somlai LS, Bandi SA, Schiraldi DA, Mathias LJ. 2006. Facile processing of clays into organically-modified aerogels. AIChE J. 52(3):1162-1168. http://dx.doi.org/10.1002/aic.10710

Wang K. 2014. Pyrolysis and catalytic pyrolysis of protein- and lipid-rich feedstock [dissertation]. [Ames (IA)]: Iowa State University. http://lib.dr.iastate.edu/etd/13936

Wang Y, Schiraldi DA. 2013. Foam-like materials produced from milk and sodium montmorillonite clay using a freezedrying process. Green Materials. 1(1):11-15. https://doi. org/10.1680/gmat.12.00005

Zarr RR, Pintar AL. 2012. NIST special publication 260175, standard reference materials: SRM 1453, expanded polystyrene board, for thermal conductivity from $281 \mathrm{~K}$ to 313 K. U.S. Department of Commerce, National Institute of Standards and Technology. http://dx.doi.org/10.6028/ NIST.SP.260-175

Zhou S, Xu Y, Wang C, Tian Z. 2011. Pyrolysis behavior of pectin under the conditions that simulate cigarette smoking. J Analytical Appl Pyrolysis. 91(1):232-240. https://doi. org/10.1016/j.jaap.2011.02.015 